\title{
PIERWSZE DNI PONTYFIKATU JANA PAWŁA II W ŚWIETLE DZIENNIKÓW JANA JÓZEFA SZCZEPAŃSKIEGO I ANDRZEJA KIJOWSKIEGO
}

Pisanie o zapiskach dziennikowych dotyczących pontyfikatu Jana Pawła II jawi się jako czynność wielce ryzykowna, grozi bowiem osunięciem się w banał. Cóż można napisać więcej, niż że ,było to wydarzenie epokowe”, ,pisarze dostrzegli historyczny sens tego wydarzenia”, „,był to moment, który obnażył słabość władzy komunistycznej w Polsce". Chyba nie do końca jestem w stanie uniknąć tego typu stwierdzeń, a nawet nie jest to niezbędne, gdyż w świetle poetyki zapisu doświadczenia osobistego często takie frazesy odsłaniają drugie, niekoniecznie banalne dno. W wypadku ,zapisków z życia” często zdarza się, że pozorny banał zakotwicza doświadczenie pisarza w wiedzy skomunalizowanej, by następnie komunał przekroczyć, wkroczyć w rejony nieoczywiste i odkrywcze. Warto pamiętać w tym kontekście o słowach Michaiła Bachtina:

\begin{abstract}
Badanie słowa ograniczające się do słowa, zapominające o jego nastawieniu na zewnątrz, jest czymś równie bezsensownym jak badanie przeżycia psychicznego poza rzeczywistością, ku której się ono zwraca i która je określa. [...] W każdym słowie wyczuwalny jest zapach kontekstu, czy kontekstów, w których przeżywało ono swoje pełne napięcia społeczne istnienie. (Cyt. za: Karpowicz 21)
\end{abstract}

W wypadku wydarzenia, które z miejsca nabrało historycznego wymiaru, kontekst - społeczny, historyczny, religijny oczywiście - jest czymś nieusuwalnym i narzucającym badaczowi tryb badania okolicznościowych wypowiedzi. A równocześnie

Dr hab. LeCh GiemZA, prof. KUL - Katedra Literatury Współczesnej w Instytucie Literaturoznawstwa KUL; adres do korespondencji: Katolicki Uniwersytet Lubelski Jana Pawła II, Al. Racławickie 14, 20-950 Lublin; e-mail: lech.giemza@gmail.com. ORCID: http://orcid.org/0000-0002-7079-9108. 
tym bardziej należy zwrócić uwagę na potrzebę indywidualizacji spojrzenia, wyjścia poza okolicznościowe (nomen omen) formułki.

Dlatego świadomie sięgam po nazwiska pisarzy, którzy niechętnie formułują gotowe diagnozy, unikają zbiorowych emocji, a do samej postaci Karola Wojtyły podchodzą z szacunkiem lecz bez namaszczenia. Wydaje mi się niezmiernie ciekawe, jak Jan Józef Szczepański i Andrzej Kijowski opisują początki pontyfikatu Jana Pawła II w swych dziennikach. Warto zauważyć, że obu pisarzy wiele łączy, choćby wieloletnia przyjaźń. Obu też charakteryzuje specyficzna relacja do chrześcijaństwa, którą Kijowski nazywa wprost: „Należę do tych, którzy krążą wokół Kościoła, nie mogąc zdecydować się ani na wejście, ani na odstąpienie" (5). Obaj więc, każdy na swój sposób, reprezentują postawę poszukującą, zdystansowaną do kulturowego modelu religijności w Polsce, równocześnie nie kryjąc fascynacji osobowością Jana Pawła II. Wreszcie, w wypadku każdego z nich, codzienne zapiski układają się po części w swoisty „dziennik duszy”, odsłaniając dramatyczne nieraz wewnętrzne zmagania, próby, poszukiwania.

Warto więc, mierząc się z tematem, zwrócić przede wszystkim uwagę na osobny punkt widzenia każdego z nich. Za każdym razem jest to próba uchwycenia religijnego, historycznego, społecznego, ale też ściśle egzystencjalnego tła. Ale też druga kwestia: bardzo często są to zapisy rozproszone wśród szeregu innych poruszanych równocześnie tematów (często w obrębie jednego zapisu dziennego, a nawet jednego akapitu) - warto więc zwrócić uwagę, w jakim kontekście się pojawiają, co stanowi ich naturalne odniesienie. Nawet bowiem jeśli chodzi o sam moment wyboru Wojtyły na papieża - w żadnym wypadku wydarzenie to nie przesłania innych, lecz im towarzyszy. Jest to interesujący zapis doświadczenia historycznego, prowadzony in statu nascendi, z punktu widzenia kogoś, kto zaledwie może przeczuwać sens tego, co się dokonuje na jego oczach.

Na początku warto zestawić zapisy dotyczące samego wyboru papieża-Polaka. Tu już widać różnice, nie tylko w ocenie, ale przede wszystkim w emocjonalnym tonie wypowiedzi. Wpis Kijowskiego pojawia się dopiero 28 października, ale zaczyna - znacząco:

Papież.

Jeszcze nie mogę ochłonąć po tym, co się stało w dniu 16 października.

Do dziewiątej wieczorem siedziałem z Olszewskim w kawiarni na Rozdrożu paplając o polityce. Ostatnie pół godziny spędziliśmy chodząc tam i z powrotem po placu i rozważając szanse Benellego, Koeniga i Willbrandta. Od trzech godzin świat wiedział, że kardynał Wojtyła jest papieżem. Nie mogłem uwierzyć w tę wiadomość, gdy ją w domu usłyszałem od Kazi. Powiedziałem od razu: to będzie wielki papież - $\mathrm{i}$ jestem o tym nadal przekonany.

Chyba nigdy nie byłem tak szczęśliwy.

To znaczy wiedziałem, że jestem szczęśliwy, a czułem się fatalnie. (50) 
Już sam początek pozwala dostrzec pewne dominanty. To przede wszystkim bardzo duże zaangażowanie emocjonalne piszącego - dostrzeżmy fakt, że szczegółowo wydobywa z pamięci detale sprzed dwunastu dni, nie ukrywa też swojego przejęcia. Analizując wpis można też założyć (nie jest to wprost napisane), że trzy godziny poświęcił na analizę i rozmowę dotyczącą konklawe i szans poszczególnych kandydatów na papieża.

Kolejna kwestia to nieustanna skłonność do samoanalizy - nawet reagując na tak wielkie wydarzenie Kijowski przygląda się bacznie sobie samemu i swym reakcjom w zastanej sytuacji. Nie wystarczy po prostu napisać: „byłem szczęśliwy”, ważne, by odnotować, jak złożone emocje kryją się za tym jednym słowem. Silny egotyzm przebija $\mathrm{z}$ całych dzienników Kijowskiego, ale też widać w nim nieustanną walkę z sobą, i w wypadku autora Kronik Dedala jest to równocześnie droga ku chrześcijaństwu. Warto na marginesie odnotować, że tak spolegliwe, pełne wiary w człowieka oceny nie przydarzały się Kijowskiemu często - tu opinia, niemal laurka wystawiona papieżowi, jest wręcz wyjątkiem. Zazwyczaj bardzo krytycznie i surowo oceniał on znajomych, nie wyłączając najbliższych. Jego rygoryzm wyraźnie uwierał jego samego.

Wpis Kijowskiego nie wyczerpuje się na bieżących wydarzeniach, lecz jest pretekstem do przywołania pierwszego i jedynego spotkania Kijowskiego z Wojtyłą. Historia jest znana, streszczę ją więc tylko: w okresie studenckim Kijowski odchodzi od Kościoła, deklaruje też swoją niewiarę, co po części jest aktem buntu wobec przesadnie religijnej matki. Jego matka zna się z Wojtyłą, napotykając znanego już w Krakowie wikarego na ulicy Kijowski manifestacyjnie przechodzi na drugą stronę - doskonale wiedząc, że Wojtyła jest znajomym matki i liczy na spotkanie. Relacja do przyszłego Papieża jest więc jaką́s figurą pars pro toto stosunku Kijowskiego do wiary. Słowa, którymi eseista puentuje to wydarzenie, mogą być po części uznane za deklarację ideową ówczesnej inteligencji:

Wojtyła zjawił się przede mną jako nowe zagrożenie, bo mnie zafascynował możliwością odnowienia wiary i pobożności na innym poziomie, dokładnie odpowiadającym moim ówczesnym aspiracjom i mojej ówczesnej literackiej formacji. [...] On był ode mnie naprawdę mądrzejszy: naprawdę - tzn. ukazywał mi rzeczy nie znane a oczekiwane, zaskakiwał, a zarazem potwierdzał to, co chciałem wiedzieć, był daleko przede mną w zdolności kojarzenia, a zarazem identyczny w stylu. (52)

Eseista mówiąc „był ode mnie mądrzejszy”, uznaje w Wojtyle mistrza i przewodnika, ale to, co zostaje wyakcentowane, dotyczy intelektualnego aspektu wiary - otwarcia na przestrzeń pytań, gotowości wspólnych poszukiwań. Celnie wyraża to użyta formuła: „ukazywał mi rzeczy nie znane a oczekiwane”. Intelektualizm w wypadku Kijowskiego nie oznacza ucieczki w racjonalizowanie zjawisk wiary, 
lecz raczej oczyszczenie z naiwności i fideizmu, ale też szczególne wyczulenie na fałsz płytkiego religianctwa. Warto w tym kontekście zwrócić uwagę na wpis sąsiadujący w dziennikach, jednakże datowany dopiero na 29 czerwca następnego roku, gdzie autor stawia pytanie o oryginalność chrześcijaństwa. Od razu też sam sobie odpowiada: „Chrześcijaństwo nie jest (prawdopodobnie) oryginalne w swej intelektualnej czy emocjonalnej warstwie, ani w środkach wyrazu, ani w formach organizacyjnych" (53). Dalsza część tej wypowiedzi idzie w kierunku faktycznej odrębności chrześcijaństwa, puenta natomiast brzmi: „Aby tak odpowiedzieć na to pytanie, trzeba przestudiować... Ba, ileż trzeba przestudiować” (54). Choć Kijowski nie szuka wiedzy religijnej, lecz osobowego spotkania z Chrystusem, to jednak poznanie naukowe pozostaje dla niego furtką do wiary.

Kolejne zapisy przynoszą rzadkie, ale celne zapisy poświęcone Papieżowi, ilość nie stanowi tu o jakości - świadczą o całkowitym ,wsłuchaniu się” w myśl Jana Pawła II, widać tu i potrzebę przedyskutowania kolejnych wypowiedzi, i potrzebę duchowego przeżycia. Równocześnie Kijowski surowo i „bez znieczulenia” opisuje swoistą idolatrię rodzącą się w Polsce; w 1984 roku pisze (za Kłoczowskim): „Zbanalizowanie nauki Jana Pawła II już się dokonało: tryumfalizm Kościoła. Spojrzeć na to ewangelicznie..." (276).

Jest w tekstach Kijowskiego pewien stały, uderzający ton, który w pewnym niezbędnym skrócie da się określić jako skrajny sceptycyzm wynikający z etycznego wyczulenia tego człowieka. W dużej mierze jest to sceptycyzm wynikający $\mathrm{z}$,zarażenia” Gombrowiczem, jest to nieustanne zmaganie się z Formą, z fałszem zakodowanym głęboko we własnym „ego”.

Dziennik Szczepańskiego zaskakuje komplementarnością wobec dziennika Kijowskiego. To fascynujące, jak obaj pisarze spotykają się na poziomie doboru opisywanych faktów, i jak równocześnie ta zbieżność uwydatnia głębokie różnice charakterologiczne, manifestujące się w emocjonalnym tonie zapisu, skupieniu na własnym ,ja”, przywiązaniu do szczegółów dnia codziennego. Dziennik Szczepańskiego ciąży bardziej ku opisowi świata zewnętrznego, choć sam autor nie stroni od zwierzeń intymnych, nieraz wręcz szokujących. Inny jest też jego stosunek do religijności - Szczepański otwarcie deklaruje niewiarę, jest to jednak model niewiary poszukującej, dalekiej z pewnością od ideowego ateizmu, zdradzający równocześnie głęboką duchowość pisarza. Stosunek do wyboru Wojtyły na papieża jest również inny niż u Kijowskiego, choć autor Polskiej jesieni przeżywa ten moment równie osobiście.

Co ciekawe, również Szczepański dowiaduje się o historycznym wydarzeniu z opóźnieniem, przy czym o ile u Kijowskiego były to trzy godziny, o tyle w tym wypadku są to aż dwa dni: 
18 X, Kraków

Wczoraj po 9-ej wiecz. w domu. Przejazd przez Węgry w gęstej mgle. Zakupy w Debreczynie. Koło południa granica czeska. [...]

O 6-ej na ostatniej granicy, już sprawnym samochodem. W domu zastaliśmy tylko małego Jasia, który poinformował nas o wyborze kard.[ynała] Wojtyły na papieża: „A wiesz, że twój znajomy jest papieżem?”. (487)

Szczepański dowiaduje się o wydarzeniu tak późno, gdyż wcześniej jest w trakcie podróży z Węgier, i żadne informacje do niego nie docierają. Dziś taka sytuacja byłaby niewyobrażalna. Ale co ciekawe - ta informacja wcale nie zdominowała jego wpisu, inaczej niż u Kijowskiego, u którego cały kilkustronicowy zapis jest podporządkowany inicjalnemu równoważnikowi zdania: „Papież” i pojawiającemu się następnie wyznaniu: „Jeszcze nie mogę ochłonąć...”. Szczepański pozostaje wierny chronologii, wiadomość nie wytrąca go z porządku codzienności, wypowiedź pozostaje stonowana. Frapuje to przywiązanie do szczegółu, zwłaszcza gdy już w następnym akapicie relacjonuje: „Za kuchnią kameleon Diany w szklanej skrzynce. Bałagan. Telefon od Anuli z rocznicowymi życzeniami. Zapomnieliśmy o tym oboje" (487).

Trudno stwierdzić, na ile to wynik przypadkowości, na ile efekt zamierzony jednak taka strategia też ma swój walor artystyczny, z pozornego chaosu wyłania się pewna całość: kameleon, telefon, zepsuty samochód, i w tym wszystkim wiadomość, która jeszcze nie dociera, nie przedziera się - dokładnie rzecz ujmując - przez powłokę codzienności. Co więcej, w tym samym wpisie pojawia się autokomentarz rzucający nieco światła na emocjonalne poruszenie pisarza: „Pobieżność tych notatek: tyle jednak wzruszenia, którego nie ma jak wyrazić. I mnóstwo uciekających rzeczy. Np. nie przyszło mi do głowy zanotować w Meteorach, kiedy dowiedzieliśmy się o śmierci papieża, tego przeczucia, prawie pewności, że to będzie miejsce dla Wojtyły" (487).

W całym pisarstwie Szczepańskiego dominuje pewien charakterystyczny ton, objawiający się również w prozie i w esejach, będący odpowiedzią na nierealność przeżytego doświadczenia historycznego; to szukanie „twardego gruntu”, próba uchwycenia materialności i niezmienności świata. Pisze Andrzej Werner:

Pozostaje więc poszukiwać w ludziach i oczywiście w sobie tego, „co uchyla się nicości”. Trzeba stanąć wobec tego, co rzeczywiste, co istnieje, i z nadzieją, lecz bez złudzeń szukać punktu oparcia. Świat nie może być tak jednoznaczny: im trwalsza rana pamięci, tym bardziej winna wzmacniać nadzieję, dobrą wolę poszukiwania. (34)

Jest więc radosna wiadomość, jaką otrzymuje Szczepański, zanurzona w nurcie wydarzeń codziennych, i w powiązaniu z nimi ujawnia dopiero swą siłę oddziaływania. Zostaje wpleciona w krąg spraw rodzinnych i tym zabiegiem zyskuje walor 
wydarzenia osobistego, ważnego bezpośrednio dla autora. Dopiero później dowiadujemy się o echach tego wydarzenia - manifestowanej przez młodzież radości na krakowskim rynku, reakcji władz. Jest w tym sposobie pisania pewien rys, również dostrzeżony przez Wernera, który dałby się określić jako autobiografizm wolny od epatowania własną osobowością:

Autobiografizm w literaturze wiąże się bardzo często z narcystyczną, a co najmniej egotyczną postawą autora. Zapatrzony w siebie, nie przestaje analizować własnych przeżyć, emocji, multiplikuje własne ego i sprawdza je w rożnych wariantach, różnych sytuacjach. Trudno o postawę bardziej nie przystającą do Jana Józefa Szczepańskiego i jego pisarstwa. (110)

O ile więc zostaje u Szczepańskiego podkreślona sprywatyzowana perspektywa spojrzenia, o tyle własny głos zostaje wyciszony, a emocje - stonowane.

Kolejne wpisy bliższe są już, co naturalne, wspólnotowej perspektywie, pisarz notuje następujące po sobie wydarzenia związane z pontyfikatem do momentu wyjazdu do Kasinki, który w dzienniku zazwyczaj oznacza krąg innych spraw. Co ciekawe, już te pierwsze wpisy ujawniają delikatnie akcentowany krytycyzm autora Rafy:

Patriotyczne (a nawet szowinistyczne) emocje, jakie rozbudził papież, zdominowane w dzisiejszej uroczystości aurą nie tylko transcendencji, ale wielkiego, światowego uniwersalizmu. [...] Wzruszenie bardzo głębokie, bardzo osobiste tym człowiekiem, który z taką godnością, taką prostotą jest nadal sobą w swej nowej, niebywałej roli. Ale też, co za widowisko! Jego powszechność i jego hieratyczna sublimacja! Największe wrażenie - seria rozmów z kardynałami, składającymi kolejno hołd. Każda z tych rozmów osobista, każda inna, inaczej zabarwiona uczuciowo. I ci starzy ludzie, padający na kolana w synowskiej pokorze, ściskani, pokrzepiani żartobliwie, troskliwie, nigdy zdawkowo. I jeszcze uczucie powrotu. Powrotu całego narodu w obręb wspólnej tradycji, na scenę wspólnej historii. (Szczepański 489)

Krytycyzm dotyczy postaw społecznych („,szowinistyczne emocje”), jednak jest przesłonięty przez plastyczność opisu uroczystości inauguracyjnych. To, co ujmuje autora, to autentyzm Papieża - ,jest nadal sobą”. Ten aspekt, autentyczności właśnie, będzie przez Szczepańskiego później wielokrotnie podkreślany. Można powiedzieć, że kibicuje Janowi Pawłowi II dyskretnie, bez ostentacji, koncentrując się raczej na ludzkim wymiarze jego posługi.

Zauważmy, że przy wszelkich różnicach oba dzienniki wykraczają poza formę suchego zapisu faktograficznego. Są próbą dookreślenia sensu tego historycznego wydarzenia. Co więcej, obaj diaryści dążą nie tylko do odpowiedzi: „,o to wydarzenie znaczy”, ale również: „co to wydarzenie znaczy dla mnie”? Mamy więc do czynienia z pewną formą duchowej autobiografii, gdzie obok prawdy historycznej pojawia się prawda doświadczenia wewnętrznego. Obaj autorzy - każdy na swój sposób - personalizują to wydarzenie. Gdy Szczepański notuje na gorąco wrażenia 
z pierwszej pielgrzymki papieskiej, to zapisuje nie tylko to, co się dzieje, ale również to, co się dokonuje:

Wczoraj poszliśmy wszyscy na dziennik TV do Juszczaków. Informacje spreparowane bardzo charakterystycznie. [...] Komentator wspomniał tylko, że „Ojciec św. wygłosił przemówienie na tematy religijne". Mimo to w gestach tego człowieka, w jego mimice czuło się obecność tłumów, które słuchają, z którymi jest w intymnym kontakcie, podczas kiedy słowa bonzów płynęły ponad głowami spędzonych rzesz w zupełnej pustce. (533)

Szczepański, wielokrotnie podkreślający swoją areligijność, dostrzega coś, co dzieje się nie tyle nawet pod powierzchnią historii politycznej, lecz nawet wbrew niej, wbrew decydentom dążącym do marginalizacji tego wydarzenia. Widzi duchowy wymiar wydarzenia, w tym wypadku pozostając na poziomie obserwacji „języka pozawerbalnego". Dostrzega nie tylko siłę przekazu Jana Pawła II, ale również wewnętrzną przemianę zachodzącą w ludziach zebranych na Wzgórzu Lecha (prawdopodobnie o tę część pobytu chodzi diaryście, gdyż wspomina o „pobieżnej relacji”, następnego dnia Papież przemawiał jeszcze przed odlotem do Częstochowy, na lądowisku w Gębarzewie). Stoimy więc wobec pewnego problemu, wobec prawdy nieweryfikowalnej, a jednak równie doniosłej, jak historyczna faktografia. Z pomocą przychodzi Philippe Lejeune:

Pakt autobiograficzny jest zobowiązaniem, jakie podejmuje autor celem opowiedzenia swego życia (lub jego części, albo jego aspektu) bezpośrednio, w duchu prawdy.

Sytuuje się w opozycji do paktu fikcji. Ktoś, kto proponuje Wam powieść (nawet inspirowaną przez własne życie), nie wymaga od Was przyjęcia w dobrej wierze tego, co opowiada; chce jedynie, byście odegrali rolę przyjmującego (tę opowieść) za prawdę.

Autobiograf obiecuje Wam, że to, co opowie, jest prawdziwe lub przynajmniej jest tym, co on sam uważa za prawdę. Zachowuje się jak historyk lub dziennikarz, z tą tylko różnicą, że podmiotem obietnicy dotyczącej prawdziwej informacji jest on sam we własnej osobie. (297)

Ufamy Szczepańskiemu nie tylko dlatego, że chcemy mu ufać, ale również dlatego, że on sam dąży do zapisu wewnętrznie uczciwego, wolnego od falsyfikowania swoich obserwacji. Zwróćmy uwagę tylko na jedno zdanie, częściowo potwierdzające tę tezę: „Nie bardzo dociera jeszcze do mnie niezwykłość tego wydarzenia, Danusia i Peggy, które odbierają to prawidłowo, czyli religijnie, są znacznie bliższe odczucia wielkości chwili” (Szczepański 533). To zdanie poprzedza zaledwie o dwa dni powyższy zapis. Autor niezwykle wyraźnie podkreśla różnicę punktów widzenia między sobą i żoną (Danusią), uznając jej prymat i odbierając sobie prawo narzucania czytelnikowi jedynie słusznej interpretacji historycznych wydarzeń.

Wracam do punktu wyjścia - choć da się uchwycić istotne różnice w sposobie potraktowania tematu przez Kijowskiego i Szczepańskiego, to ich opisy pierwszych dni pontyfikatu Jana Pawła II łączy próba uchwycenia historii „długiego trwania” - 
stawiają pytania nie tylko w perspektywie aktualnych uwarunkowań geopolitycznych, lecz ostrożnie formułują sądy sięgające poza horyzont doczesności, przypisując sobie rolę wykraczającą poza miano „kronikarza”. Takim kronikarskim zapisem (choć niepozbawionym emocji i elementu oceny) jest adnotacja w Dzienniku Mariana Brandysa:

Wszyscy i wszędzie mówią o jednym: o wyborze polskiego papieża. Kardynał krakowski Karol Wojtyła wysunął się na pierwsze miejsce w szeregu bohaterów całego tysiąclecia historii Polski. „Człowieka ogrania taka duma - mówi Tośka swoim dosadnym językiem - jakby tego Wojtyłę urodził".

Wczoraj wieczorem telewizja polska nadała krótki reportaż z Rzymu. Było to bardzo interesujące. Nowy papież, autentycznie wzruszony aż do łez, przemawiał po włosku do dwustutysięcznego tłumu Włochów i co chwila przerywano mu oklaskami. Łzy nowego papieża były zrozumiałe. Jego nowa sytuacja będzie niezwykle trudna. (169)

Brandys przyjmuje od razu perspektywę ogólną, narodową, oddając na chwilę głos swojej wychowanicy - Antoninie Krzysztoń. Jest to już spojrzenie pozbawione osobistej refleksji, uwagi Brandysa są natury ogólnej, raczej odnoszą się do sytuacji w kraju. Nie znaczy to, że taki „reporterski” głos jest mniej ważny. Pozwala dostrzec wachlarz postaw pisarzy, dla których wybór Polaka na tron papieski był wydarzeniem ważnym, okazuje się jednak, że skala ważności w każdym z tych trzech dzienników jest nieco inna.

\title{
BIBLIOGRAFIA
}

Brandys, Marian. Dziennik 1978. Iskry, 1997.

Karpowicz, Agnieszka. Proza życia. Mowa, pismo, literatura. Wydawnictwa Uniwersytetu Warszawskiego, 2012.

Kijowski, Andrzej. Dziennik 1978-1985. Wydawnictwo Literackie, 1999.

Lejeune, Philippe. Wariacje na temat pewnego paktu. O autobiografii. Universitas, 2001.

Szczepański, Jan Józef. Dziennik, t. IV: 1973-1980, Wydawnictwo Literackie, 2015.

Werner, Andrzej. Wysoko, nie na palcach. O pisarstwie Jana Józefa Szczepańskiego. Wydawnictwo Literackie, 2003.

\author{
PIERWSZE DNI PONTYFIKATU JANA PAWŁA II \\ W ŚWIETLE DZIENNIKÓW JANA JÓZEFA SZCZEPAŃSKIEGO \\ I ANDRZEJA KIJOWSKIEGO
}

Streszczenie

Artykuł jest poświęcony strategiom opisu pierwszych dni pontyfikatu Jana Pawła II w Dziennikach Andrzeja Kijowskiego i Jana Józefa Szczepańskiego. Dla obu postać Papieża jest ważna, jednak widać wyraźne różnice w podejściu do tematu. Wpisy Kijowskiego są całkowicie podporządkowane 
temu wydarzeniu, Szczepański traktuje je na równych prawach z wydarzeniami dnia codziennego. Dla Kijowskiego jest to przede wszystkim wydarzenie o charakterze religijnym, Szczepański odczytuje je w kontekście historycznym, odnotowując również reakcje społeczeństwa polskiego. Co łączy obu, to podkreślenie duchowego wymiaru tego wydarzenia i osobiste, emocjonalne zaangażowanie. Celem artykułu jest pokazanie początku pontyfikatu Jana Pawła II w kategoriach doświadczenia osobistego, opierając się na metodzie porównawczej.

Słowa kluczowe: Andrzej Kijowski; Jan Józef Szczepański; dziennik; Jan Paweł II

\section{THE FIRST DAYS OF JOHN PAUL II'S PONTIFICATE \\ IN LIGHT OF THE DIARIES OF JAN JÓZEF SZCZEPAŃSKI \\ AND ANDRZEJ KIJOWSKI}

\section{Sum mary}

This paper investigates the strategies employed by Andrzej Kijowski and Jan Józef Szczepański in their Dzienniki (Diaries) as they describe the early days of the pontificate of Pope John Paul II. While, clearly, the Pope is of great significance to both authors, there are considerable differences in their approaches towards him. Kijowski's entries are completely subordinated to the event, whereas in Szczepański's they seem to barely coexist with others. The former sees it primarily as a religious event, and the latter sets it in a historical context, while also noting the reactions within Polish society. The texts both underline the spiritual dimension of the event and emphasise the personal, emotional commitment of the authors. This article employs the comparative method in an attempt to present the emerging pontificate of Pope John Paul II as a personal experience.

\section{Translated by Szymon Szabelski}

Keywords: Andrzej Kijowski; Jan Józef Szczepański; diary; John Paul II 